Research Article

Animal Genetics

\title{
Influence of hypoxia on biochemical aspects and on expression of genes related to oxygen-homeostasis of the Amazonian cichlid Astronotus ocellatus (Agassiz, 1831)
}

\author{
José L. Vasconcelos-Lima ${ }^{1}$ (D), Vanessa L. Oikawa-Cardoso ${ }^{1}$ (D), Waldir Heinrichs-Caldas ${ }^{1}$ (D) \\ and Vera M. F. Almeida-Val ${ }^{1}$ (D) \\ ${ }^{I}$ Instituto Nacional de Pesquisas da Amazônia, Laboratório de Ecofisiologia e Evolução Molecular (LEEM), \\ Manaus, AM, Brazil.
}

\begin{abstract}
Variations in dissolved oxygen levels are common in the Amazonian aquatic environments and the aquatic organisms that inhabit these environments developed a variety of adaptive responses to deal with such conditions. Some Amazonian fish species are tolerant to low oxygen levels and the cichlid Astronotus ocellatus is one of the most hypoxia-tolerant species. Herein, we aimed to unveil the biochemical and molecular responses that $A$. ocellatus presents when submitted to hypoxia. Hypoxia indicators were measured, such as plasma glucose, plasma lactate, hepatic glycogen and relative transcript levels of prolyl hydroxylase 2 ( $p h d 2)$ and hypoxia-inducible factor-1 $\alpha$ (hif-1 $\alpha)$ in juveniles of approximately $50 \mathrm{~g}$ exposed to 1,3 , and 5 hours of hypoxia $\left(0.7 \mathrm{mg} \mathrm{O}_{2} \cdot \mathrm{L}^{-1}\right)$, followed by 3 hours of recovery in normoxia $\left(6 \mathrm{mg} \mathrm{O}_{2} \cdot \mathrm{L}^{-1}\right)$. Fish exposed to hypoxia reduced liver glycogen levels within 3 hours of hypoxia, when comparing with 1 hour, and increased plasma glucose and lactate. Under the same condition, phd2 transcripts levels increased in gills, but decreased in liver. In contrast, hypoxia did not affect relative gene expression of hif-1a in both tissues. Based on the transcription pattern of phd2, these results showed that liver and gills of $A$. ocellatus have different molecular strategies to cope with environmental hypoxia.
\end{abstract}

Keywords: Amazon, glucose, glycogen, hif-1 $\alpha$, phd2.

Received: May 06, 2021; Accepted: September 06, 2021.

\section{Introduction}

The annual and regular variation of water level of the Amazon basin rivers described by Junk et al. (1989) as the "flood pulse" is the main driving force responsible for the productivity, existence and interaction between the biota and the river-floodplain system. Selective pressures for adaptations can be explained by various environmental challenges faced by these organisms during their lifespan, like short- and longterm changes in water $\mathrm{pH}$, ion availability, temperature and availability of dissolved oxygen (Almeida-Val et al., 1999). The Amazonian fishes present biochemical, physiological and behavioral adaptations to deal with hypoxic environments (Val et al., 1998). These adaptive responses can be related to reduced energy demand, improved oxygen uptake, or simply avoidance of hypoxic areas (Val, 1995; Muusze et al., 1998; Almeida-Val et al., 1999; Sloman et al., 2006). Although hypoxia is not lethal for some fish species, sublethal effects may influence the biological functions of an organism and, consequently, its fitness (Cheung et al., 2014). Compared to other Amazonian fishes, Astronotus ocellatus (also known as Oscar fish) is a highly hypoxia tolerant Cichlidae species (Muusze et al., 1998; Sloman et al., 2006). Adult individuals can tolerate

Send correspondence to Vera M. F. Almeida-Val. Instituto Nacional de Pesquisas da Amazônia, Laboratório de Ecofisiologia e Evolução Molecular (LEEM), Av. André Araújo, 2936, 69067-375, Manaus, AM, Brazil. E-mail: veraval30@gmail.com.

All the authors contributed equally to the study.
$5-20 \%$ of air-saturated oxygen tension for a period of 20 to 50 hours and, in anoxic condition, their tolerance period is up to 6 hours at $28^{\circ} \mathrm{C}$ (Muusze et al., 1998). This high hypoxia tolerance is product of a series of physiological adjustments aimed to reduce the oxygen demand. The remarkable hypoxia tolerance of Astronotus ocellatus is primarily based on the aerobic metabolism depression followed by an activation of the anaerobic glycolysis (Muusze et al., 1998; Scott et al., 2008). When exposed to hypoxia in the wild, $A$. ocellatus remains in place, an ecological behavior allowed by its adaptations and high tolerance to hypoxia.

Organisms under hypoxia show numerous physiological and molecular outcomes of the expression of several genes regulated by hypoxia with fundamental importance for its homeostasis (Nikinmaa and Rees, 2005). The hypoxiainducible transcription factor (HIF) is stabilized in response to reductions of oxygen levels (Maxwell et al., 1999). HIF-1 is a heterodimer protein composed of two subunits, HIF1- $\alpha$ and HIF $1-\beta$, expressed by the hif- $1 \alpha$ and hif- $1 \beta$ genes, respectively. Both subunits contain a basic helix-loop-helix (bHLH) and a PAS domain (Per, ARNT, Sim), required for heterodimerization, DNA binding and transactivation (Kewley et al., 2004; Nikinmaa and Rees, 2005). The protein HIF-1 binds to specific regions of the DNA and regulates the transcription of oxygen-regulated genes (Wenger et al., 2005).

In fish, some target genes are known, such as erythropoietin (epo), glucose transporter 1 (slc2al), lactate dehydrogenase $\mathrm{B}(l d h b)$, and vascular endothelial growth factor A (vegfa) (Rashid et al., 2017). According to Kodama et al. (2012), HIF 
is an evolutionarily conserved in vertebrates, acting as the main regulator of gene expression in cells exposed to hypoxia.

Studies with vertebrates indicate that the HIF- $1 \alpha$ subunit is constantly synthesized, being rapidly degraded under normal oxygen conditions (Semenza, 2004). Its degradation is mediated by a specific region called oxygen-dependent degradation domain (ODD). Under normal oxygen condition, this domain has two conserved proline residues, which are covalently modified by the action of the prolyl-hydroxylase (PHD) (Nikinmaa and Rees, 2005). There are three functional isoforms of the PHD enzyme: PHD1, PHD2, and PHD3, expressed by $p h d 1, p h d 2$, and $p h d 3$ genes, respectively. Each isoform differs in the mRNA relative abundance, but all forms show the same pattern of ubiquitous expression in human cells (Cioffi et al., 2003). Among the three PHD isoforms in human cells, PHD2 has the highest affinity for HIF-1 $\alpha$ (Berra et al., 2003; Appelhoff et al., 2004). PHDs detect and utilize oxygen as substrate to insert the hydroxyl group onto the proline residues of the HIF-1 $\alpha$ subunit. The hydroxylation reaction of PHDs requires 2-oxoglutarate and iron as cofactors. When HIF proline residues are hydroxylated, HIF-1 $\alpha$ is recognized by the von-Hippel-Lindau (pVHL) protein, ubiquitinated and degraded by the proteasome pathway in the $26 \mathrm{~S}$ proteasome (Epstein et al., 2001; Nikinmaa and Rees, 2005; Kaelin Jr and Ratcliffe, 2008; Rytkönen et al., 2011).

In hypoxic conditions, PHD enzyme activity levels are inhibited due to the low oxygen saturation (Nikinmaa and Rees, 2005). Thus, HIF-1 $\alpha$ protein is stabilized, accumulates and is transferred from the cytoplasm to the nucleus, where it binds to the HIF-1 $\beta$ subunit, forming HIF-1 transcription factor. HIF-1 will associate with the general transcription factors (CBP/p300) and bind to Hypoxia Responsive Elements (HRE), which are conserved sequences located in the promoter regions of induced genes by hypoxia. Thus, HIF-1 target genes are related to the processes of angiogenesis, erythropoiesis, glycolysis, iron transport, apoptosis and cell cycle control (Nikinmaa and Rees, 2005; Kaelin Jr and Ratcliffe, 2008; Rytkönen et al., 2011).

Considering the high hypoxia tolerance of Oscars in nature and laboratory experiments, and considering the above described processes of PHD-HIF oxygen-sensing system, since this is responsible for most of hypoxia responsive elements, in this study we aimed to understand how these two genes contribute to the adaptive responses to hypoxia in Astronotus ocellatus and how they might be involved in this animal's hypoxia responses, such as the switch to anaerobic metabolism and metabolic depression.

\section{Material and Methods}

\section{Experimental animals}

Juveniles of $A$. ocellatus ( $5 \mathrm{~g} \pm 0.5)$ were purchased from a commercial supplier (Fish Farm Santo Antônio, Rio Preto da Eva City, Amazonas, Brazil), and transferred to the Laboratory of Ecophysiology and Molecular Evolution (LEEM) at National Institute for Amazon Research (INPA), Manaus, Amazonas, Brazil, for acclimation. The animals were held outdoors in $500 \mathrm{~L}$ tanks with aerated water (approximately $7 \mathrm{mg} \mathrm{O} \cdot \mathrm{L}^{-1}$ ) at $27^{\circ} \mathrm{C} \pm 2, \mathrm{pH}$ varying between 5 and 6 , under constant water renewal and natural light exposure. The animals were reared in this condition during approximately three months until they reached the experimental weight, which was 50 grams. Fishes were fed once a day until satiation with commercial pelleted food ( $36 \%$ protein). Feeding was suspended 24 hours prior the experiments.

\section{Experimental design: Hypoxia exposure and recovery in normoxia}

The experimental protocol was carried out in accordance with the Brazilian Guidelines for Use and Care of Animals (CONCEA), with the authorization of INPA's Committee for Ethics in Animal Use (CEUA protocol \#022/2017), and no fish died during the hypoxia exposition.

Forty-eight juveniles of $A$. ocellatus, weighing 49.6 $\pm 0.9 \mathrm{~g}$, were used. For the experiment, two $100 \mathrm{~L}$ tanks were used and four fish were placed in each tank 24 hours prior the beginning of the experiment for acclimation. Water temperature was maintained at $28^{\circ} \mathrm{C}$ and the whole experiment was carried out indoors. The animals were kept separated by grids so they did not have contact with each other. For hypoxia treatment, the aeration of one tank was interrupted and $\mathrm{N}_{2}$ gas was pumped into the water until the oxygen level reached $0.7 \mathrm{mg} \mathrm{O} \mathrm{O}_{2} \cdot \mathrm{L}^{-1} \pm 0.5$. The tank was covered with bubble wrap to prevent oxygen diffusion from the air. The animals were submitted to hypoxia for 1 hour, 3 hours and 5 hours, followed by 3 hours of recovery when the aeration was taken back to normoxic concentration $\left(6 \mathrm{mg} \mathrm{O}_{2} \cdot \mathrm{L}^{-1} \pm 0.5\right)$. For the control, the aeration of the other tank were constant throughout the whole experiment $\left(6 \mathrm{mg} \mathrm{O}_{2} \cdot \mathrm{L}^{-1}\right)$. One animal from each tank was sampled after 1,3 , and 5 hours, followed by 3 hours of recovery. This experiment was repeated six times, thus six animals was sampled for each period. At the end of the experiment, twenty-four animals were used for control and twenty-four animals for hypoxia treatment.

In order to assure the animals were in hypoxia, the oxygen concentration for hypoxia treatment was approximately half of the critical oxygen level $\left(P_{2 \text { crit }}\right)$ value found by De Boeck et al. (2013) for $A$. ocellatus and was the concentration was similar to the one used by Baptista et al. (2016). Three hours of recovery in normoxia was chosen because this recovery period was enough for protein synthesis to return to normal levels in gills and liver of $A$. ocellatus, as described by Lewis et al. (2007). The dissolved oxygen level was monitored using WITROX 4 and DAQ-M equipment (Loligo System, Viborg, Denmark), combined with the commercial software AutoResp (Loligo System, Viborg, Denmark).

\section{Blood and tissue sampling}

Right after the experiment, blood samples were quickly collected from the caudal vein, with heparinized syringes, and centrifuged for plasma separation. Then, the animals were euthanized by concussion followed by severing of the spinal cord. Gills and liver were removed and promptly frozen in liquid nitrogen. All the biological samples were stored at $-80^{\circ} \mathrm{C}$ for further analysis.

\section{Biochemical assays}

Plasma glucose determination was performed with the colorimetric enzymatic glucose kit (InVitro, MG, Brazil), according to manufacturer's instructions. For plasma lactate 
quantification, total plasma was acidified with $8 \%$ perchloric acid and centrifuged at $604 \mathrm{~g}$ for $10 \mathrm{~min}$. The supernatant was removed and neutralized with $6 \mathrm{M}$ potassium hydroxide, and centrifuged at $604 \mathrm{~g}$ for $3 \mathrm{~min}$. The supernatant was transferred into a microplate with glycine buffer (G5418, Sigma-Aldrich, CA, USA), $\beta$-nicotinamide adenine dinucleotide hydrate (N6522, Sigma-Aldrich, CA, USA) and L-lactic dehydrogenase (L2500, Sigma-Aldrich, CA, USA). The microplate was incubated at $37{ }^{\circ} \mathrm{C}$ for approximately $10 \mathrm{~min}$. The reading was performed using a microplate reader (SpectraMax M, Molecular Devices, CA, USA) at the wavelength of $340 \mathrm{~nm}$.

Liver glycogen quantification was performed according to Bidinotto et al. (1997). Liver sample (approximately 0.03 g) was placed inside a microtube containing $6 \mathrm{~N}$ potassium hydroxide. The microtube was placed in a dry bath at $98{ }^{\circ} \mathrm{C}$ until total liver dissolution. Subsequently, $96 \%$ ethanol and $10 \%$ potassium sulfate were added to the microtube. The solution was centrifuged and the supernatant discarded. Pure water was added and used to resuspend the white sediment (Bidinotto et al., 1997). An aliquot was withdrawn, and 3\% of phenol and sulfuric acid were added to it. The solution was mixed, and incubated for $10 \mathrm{~min}$ at $25{ }^{\circ} \mathrm{C}$ (Dubois et al., 1956). The reading was performed using a microplate reader (SpectraMax M, Molecular Devices, CA, USA) at the wavelength of $480 \mathrm{~nm}$.

\section{Total RNA extraction and first-strand cDNA synthesis}

Total RNA was isolated from gills and liver using TRIzol Reagent (Invitrogen, CA, USA) according to the manufacturer's instructions. Total RNA was quantified with NanoDrop 2000 spectrophotometer (Thermo Scientific, MA, USA). The integrity of the RNA was verified by $1 \%$ agarose gel electrophoresis, showing intact $28 \mathrm{~S}$ and $18 \mathrm{~S}$ rRNA bands. Total RNA was diluted to a final concentration of $500 \mathrm{ng}$ with nuclease-free water, and was treated with DNase I Amplification Grade (Invitrogen, CA, USA). cDNA synthesis was obtained using total RNA and High Capacity cDNA Reverse Transcription Kit (Applied Biosystems, CA, USA), according to manufacturer's protocol.

\section{Sequencing and primer obtention}

A BlastN search was performed (www.ncbi.nlm.nih.gov/ BLAST/) on the complete, non-redundant GenBank nucleotide database for ortholog of $p h d 2$ in other fish species. A multiple sequence nucleotide alignment was carried out on coding sequences to design the primers. The specific sequences were obtained through the Sanger protocol using ABI 3130 (Applied Biosystems, CA, USA) following the ABI PRISM ${ }^{\circledR}$ Big Dye $^{\mathrm{TM}}$ Terminator Cycle Sequencing Ready Reaction (Applied Biosystems, CA, USA) protocol. The obtained sequences were analyzed through ABI 3130 Sequence Analyzer software (Applied Biosystems, CA, USA) for their electropherograms quality parameters. The contigs were generated using the BlastN validated tool for the detection of nucleotide homology on NCBI (www.ncbi.nlm.nih). Primers were designed using Oligo Explorer 1.5 software. The annealing temperature was optimized by gradient PCR. phd2 primers sequence used in Quantitative real-time PCR (qPCR) assays was: Forward primer: 5'-AAGTTGTCGGTTAGTAGGGC-3' and Reverse primer: 5'-TCGNTCTGCGGCTTCTCCA-3'.

\section{Real-time quantitative PCR}

In triplicate, cDNA was used for qPCR analysis, which was performed using Fast SYBR ${ }^{\circledR}$ Green Master Mix (Applied Biosystems, CA, USA) on ViiA 7 PCR-System (Applied Biosystem, CA, USA). Besides $p h d 2$, the primer sequences for hif- $1 \alpha$ and housekeeping genes, $18 S$ and $\beta$-actin, as described by Baptista et al. (2016), were:

\section{$18 s$ forward: 5'-GGGAGGTTCGAGACGATCAG-3' $18 s$ reverse: 5 '-TCGCTAGTTGGCATCGTTTATG-3'}

\section{$\beta$-actin forward: 5'-CCTTGATGTCACGCACGATT-3' $\beta$-actin reverse: 5'-CAGAGCGTGGCTATTCCTTCA-3'}

\section{hif-1 $\alpha$ forward: 5'-GGAGAGCACCAACGGACAA-3'} hif-1 $\alpha$ reverse: $5^{\prime}$-GGGTCACAGATCAAAACCAGGTA-3'

The amplification of housekeeping genes was constant during the experiment, qualifying them as strong housekeeping genes for hypoxia. The efficiencies of these four genes were approximately $100 \%$, which ensures the correct use of $\Delta \mathrm{Cp}$ equation. qPCR mix contained $5 \mu \mathrm{L}$ Fast $\mathrm{SYBR}^{\circledR}$ Green Master Mix (Applied Biosystems, CA, USA), $2 \mu \mathrm{L}$ nuclease-free water, $1 \mu \mathrm{L}$ cDNA, $1 \mu \mathrm{L}$ forward primer $(2.5 \mathrm{pmol})$ and 1 $\mu \mathrm{L}$ reverse primer $(2.5 \mathrm{pmol})$. qPCR assays were performed under the following conditions: denaturation during $20 \mathrm{~s}$ at 95 ${ }^{\circ} \mathrm{C}$, then 40 cycles: $1 \mathrm{~s}$ at $95^{\circ} \mathrm{C}, 20 \mathrm{~s}$ at $60^{\circ} \mathrm{C}, 15 \mathrm{~s}$ at $95^{\circ} \mathrm{C}$, with data collection after each cycle. Next, the melting curve analysis was performed to ensure the presence of a single product-specific melting temperature. To calculate the target gene relative quantification, RT-qPCR efficiency corrected calculation model was used according to Pfaffl (2004).

\section{Statistical analysis}

One-way ANOVA was performed to analyze physicochemical parameters of water. Relative gene expression and biochemical assays were examined for each exposure time between normoxia, hypoxia and recovery. For this, bidirectional analysis of variance (two-way ANOVA), followed by Holm-Sidak post hoc test, was used. Significance level was determined as $\alpha=0.05$. Data were expressed as mean \pm s.e.m. (standard error of the mean). Statistical analysis were performed using SigmaStat (v. 3.5) and graphics were built in SigmaPlot software (v. 11.0).

\section{Results}

\section{Biochemical aspects}

Exposure to 3 hours of hypoxia induced a decrease in liver glycogen when compared to 1 hour of hypoxia $(p<0.004$; $\mathrm{F}=5.12$ ) (Figure 1A). Otherwise, after 1, 3, and 5 hours of hypoxia exposure, plasma glucose $(\mathrm{p}<0.001 ; \mathrm{F}=59.57)$ (Figure $1 \mathrm{~B})$ and plasma lactate $(\mathrm{p}<0.001 ; \mathrm{F}=94.12)$ (Figure 1C) increased, when compared to normoxia. After 3 hours of recovery in normoxia, glucose level remained elevated, but lactate returned to the original levels found in normoxia.

\section{Relative gene expression}

Liver and gills presented inverse relative expression patterns for $p h d 2$ mRNA levels. In liver, hypoxia caused 

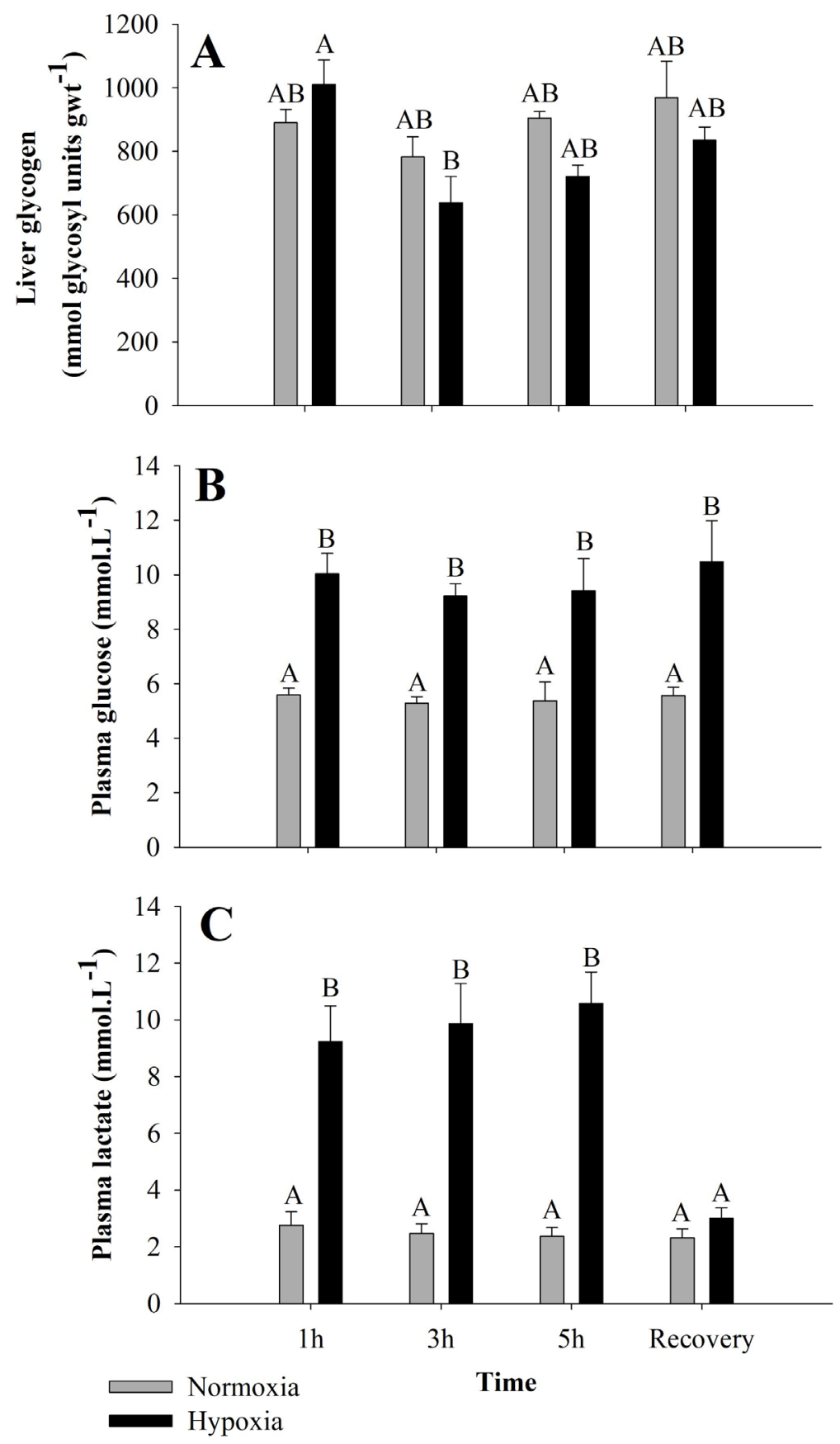

Figure 1 - Liver glycogen (A), plasma glucose (B), and plasma lactate (C) levels in A. ocellatus exposed to normoxia (6 mg $\left.\mathrm{O}_{2} . \mathrm{L}^{-1} \pm 0.5\right)$ and hypoxia $\left(0.7 \mathrm{mg} \mathrm{O}{ }_{2} \cdot \mathrm{L}^{-1} \pm 0.05\right)$ for 1,3 and 5 hours, and recovery $\left(6 \mathrm{mg} \mathrm{O}_{2} \cdot \mathrm{L}^{-1} \pm 0.5\right)$ for 3 hours (mean \pm s.e.m., $\left.\mathrm{n}=6\right)$. Statistical significance was analyzed using a two-way ANOVA. Bars with different letters indicate difference between time, normoxia, hypoxia and recovery ( $\mathrm{p}<0.05$ ).

a reduction in $p h d 2$ transcript levels $(\mathrm{p}<0.001 ; \mathrm{F}=33.79)$ compared to normoxia (Figure 2A). In gills, hypoxia increased phd 2 transcripts $(\mathrm{p}<0.001 ; \mathrm{F}=96.28)$ when compared to normoxia (Figure $2 \mathrm{~B}$ ). In both cases, the recovery returned the $p h d 2$ transcripts to normoxia levels.

In liver, hif- $1 \alpha$ showed no difference in expression between normoxia and hypoxia $(\mathrm{p}=0.683 ; \mathrm{F}=0.170)$ (Figure $3 \mathrm{~A})$; the same occurred in gills $(\mathrm{p}=0.101 ; \mathrm{F}=2.91)$ (Figure $3 \mathrm{~B})$.

\section{Discussion}

With three hour of hypoxia, glycogen content decreased in liver of A. ocellatus (Figure 1A). Similar response has also been observed in the congeneric cichlid Astronotus crassipinnis by Chippari-Gomes et al. (2005). The reduction of hepatic glycogen during hypoxia is a well-known fish response to improve its tolerance to low oxygen availability (Heath and Pritchard, 1962; Chen et al., 2007; Padmavathy and Ramanathan, 2010; Chen et al., 2017). The hepatic glycogenolysis caused by hypoxia increases the levels of plasma glucose in order to supply energy to the body in anaerobic conditions through anaerobic glycolysis (Scarabello et al., 1992; Schulte et al., 1992; Chippari-Gomes et al., 2005). The same was observed with our present results, after 3 hours of hypoxia, there is a decrease in liver glycogen and an increase 

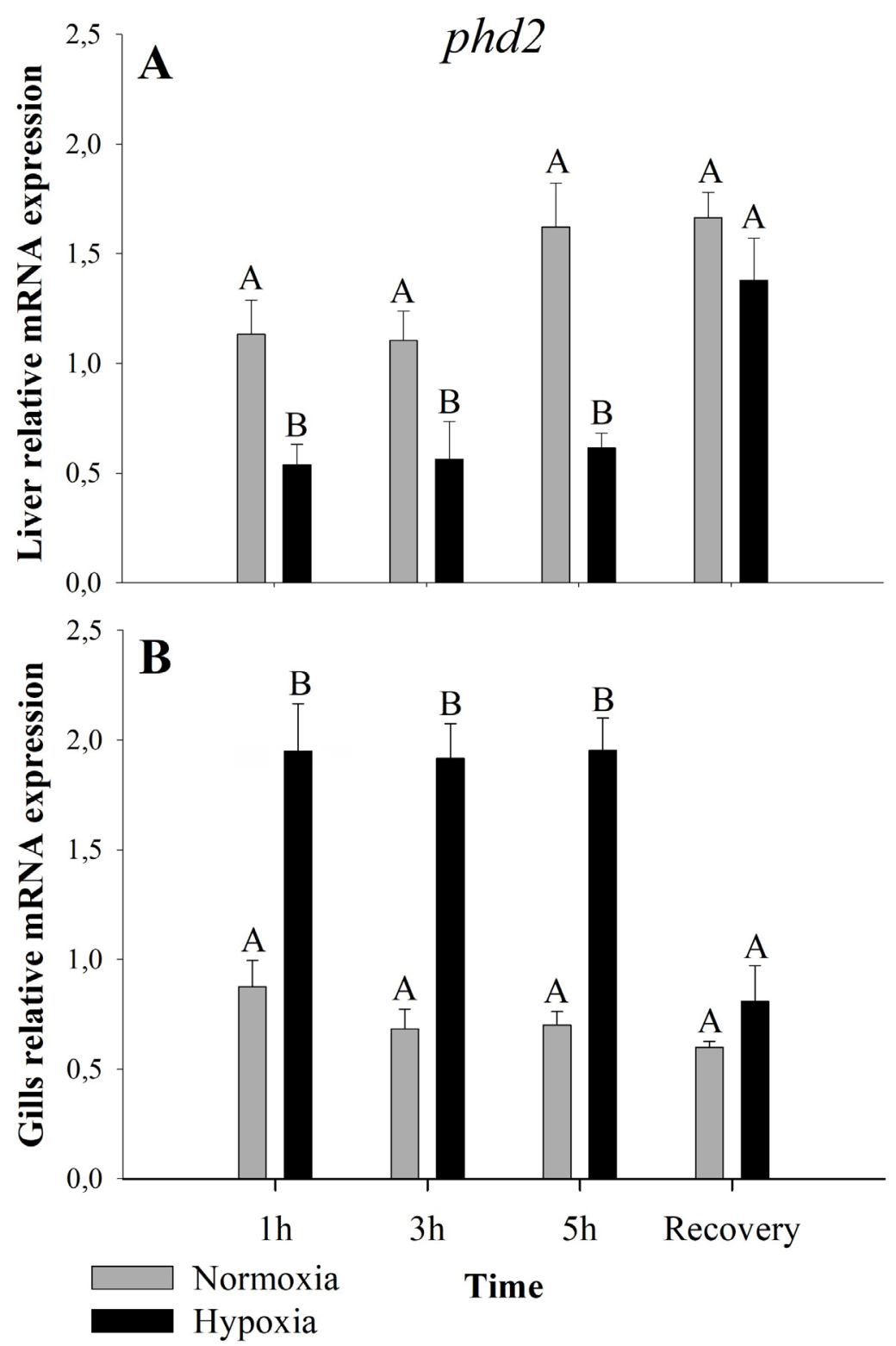

Figure 2 - Relative expression of phd2 in liver (A) and gills (B) of A. ocellatus exposed to normoxia $\left(6 \mathrm{mg} \mathrm{O}_{2} \cdot \mathrm{L}^{-1} \pm 0.5\right)$ and hypoxia $\left(0.7 \mathrm{mg} \mathrm{O}_{2} . \mathrm{L}^{-1}\right.$ \pm 0.05 ) for 1,3 and 5 hours and recovery $\left(6 \mathrm{mg} \mathrm{O}_{2} \cdot \mathrm{L}^{-1} \pm 0.5\right)$ for 3 hours (mean \pm s.e.m., $\mathrm{n}=6$ ). Statistical significance was analyzed using a two-way ANOVA. Bars with different letters indicate difference between time, normoxia, hypoxia and recovery $(\mathrm{p}<0.05)$.

in plasma glucose and lactate. An increase on plasma glucose and plasma lactate levels were also observed in A. ocellatus under different hypoxia conditions by Muusze et al. (1998), Richards et al. (2007), Wood et al. (2007), Baptista et al. (2016) and by Heinrichs-Caldas et al. (2019) in the congeneric A. crassipinis. These authors observed that plasma lactate concentration, under hypoxia stress, increased, and during the recovery phase, plasma lactate returned to values close to the control. Our results indicate a glycogen mobilization, caused by hypoxic stress, along with an increase in glucose transport. The increase observed in blood lactates levels also indicate the switch to an anaerobic metabolism.

Fishes exposed to hypoxia during 1, 3, and 5 hours, showed a phd 2 liver transcripts decrease, but increased its levels during the recovery phase, returning to similar levels found in normoxia (Figure 2A). This result contrasts with the literature, which reported an increase in liver $p h d 2$ transcripts of other fish species submitted to hypoxia (Wang et al., 2015; Zhang et al., 2017). The lower level of liver $p h d 2$ transcripts and, consequently, and presumably the low PHD2 protein activity, due to the hypoxia condition, allow HIF-1 protein to bind to its target genes (Rytkönen et al., 2011). Thereby, HIF1 induces the expression of a wide variety of genes required for an organism to survive in situations where there is a lack of oxygen, as described by Wenger et al. (2005).

As stated before, HIF-1 has several targets related to hypoxia exposition. For example, lactate dehydrogenase-A gene $(l d h-a)$, one of the target genes of HIF-1 protein (Semenza, 1998, 2002; Cui et al., 2017). Thus, the reduction of $p h d 2$ transcripts may be related to an increase in $l d h$ - $a$ transcription, as reported by Suhara et al. (2015) in mouse liver cells. Heinrichs-Caldas et al. (2019) measured LDH activity in the liver of $A$. crassipinnis submitted to hypoxia, followed by recovery in normoxia, and observed an increase in LDH 

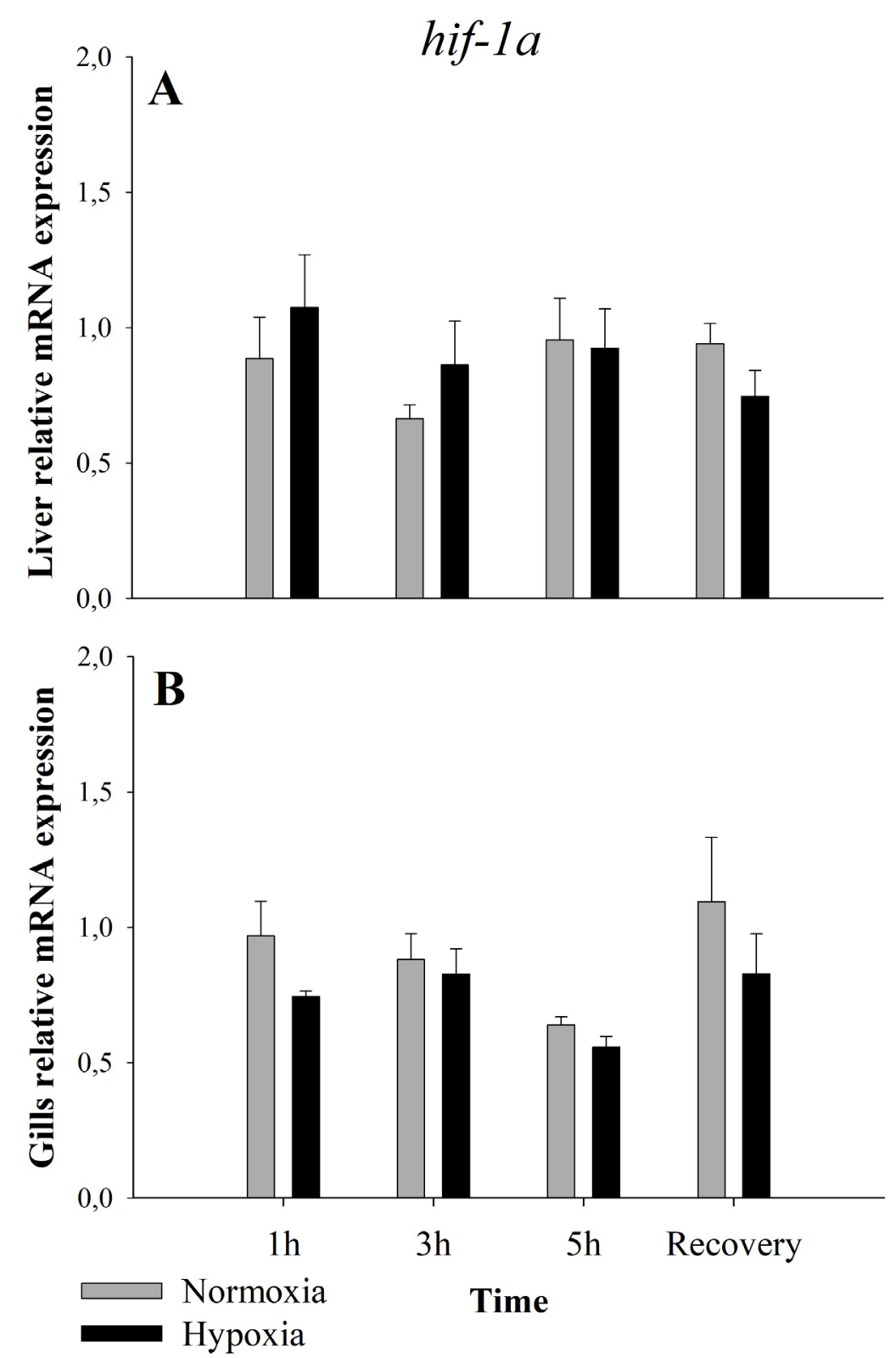

Figure 3 - Relative expression of hif-1 $\alpha$ in liver (A) and gills $(\mathbf{B})$ of $A$. ocellatus exposed to normoxia $\left(6 \mathrm{mg} \mathrm{O}_{2} . \mathrm{L}^{-1} \pm 0.5\right)$ and hypoxia $\left(0.7 \mathrm{mg} \mathrm{O}_{2} . \mathrm{L}^{-1}\right.$ $\pm 0.05)$ for 1,3 and 5 hours and recovery $\left(6 \mathrm{mg} \mathrm{O}_{2} \cdot \mathrm{L}^{-1} \pm 0.5\right)$ for 3 hours (mean \pm s.e.m., $\mathrm{n}=5$ ).

activity in animals submitted to 5 hours of hypoxia and a decrease in the enzyme activity after recovery in normoxia. All these data suggest that $\mathrm{LDH}$ responds to hypoxia accumulating lactate, which after recovery, is converted to glycogen, as suggested by Hochachka and Somero (1984), to avoid the toxicity caused by lactate accumulation in the organs (AlmeidaVal and Val, 1993). Another HIF-1 target is the vegf. Baptista et al. (2016) showed that $A$. ocellatus presents an increase in vegf transcripts levels when exposed to 3 hours of hypoxia, accompanied by an increase in hif- $1 \alpha$ transcript levels, which indicates an increase in HIF-1 activity.

Gill phd 2 transcript levels increased in hypoxia exposure and returned to normoxia level during the recovery phase (Figure 2B). The increase of phd 2 transcripts in the gills during hypoxia contrasts with the data obtained by Wang et al. (2015), which verified a decrease of phd2 expression in the gills of Megalobrama amblycephala submitted to hypoxia during four hours. Hypoxia allows HIF-1 protein to stabilize and to act as a transcription factor that binds to the HRE region of its target genes, such as phd2, that also has a HRE region (D'Angelo et al., 2003; Aprelikova et al., 2004; Metzen et al., 2005; Stiehl et al., 2006; Rytkonen et al., 2012). Consequently, we hypothesize that these high levels of phd 2 transcripts in the gills herein exposed to hypoxia were induced by HIF-1. This feedback mechanism involving phd 2 and HIF-1 protein was already observed in human cells (Marxsen et al., 2004; Pescador et al., 2005) and fish liver cells (Zhang et al., 2017) the same as other feedback loop found related to $p h d$ and hif- $1 \alpha$ (Kaelin, 2005). The increased levels of the phd2 works as an anticipation mechanism to interrupt the hypoxic responses through the degradation of HIF- $1 \alpha$ subunit when oxygen returns to its normal level (D'Angelo et al., 2003; Marxsen et al., 2004). We believe that this feedback mechanism is related to protein synthesis, once 
PHD2 also hydroxylates proteins related to protein synthesis in normoxia, as the eukaryotic elongation factor 2 kinase (eEF2K). In hypoxia, due to decreased efficiency of PHD2, eEF2K will not be hydroxylated and will become capable of phosphorylating the eukaryotic elongation factor 2 (eEF2), causing a reduction of protein synthesis for ATP and amino acids preservation (Romero-Ruiz et al., 2012; Moore et al., 2015). A reduction of $50-55 \%$ in protein synthesis rates was observed in the gills of $A$. ocellatus exposed to hypoxia by Cassidy et al. (2018). Thus, we believe that the high levels of gills $p h d 2$ transcripts during hypoxia may be important for the resumption of protein synthesis during reoxygenation.

No differences of hif- $1 \alpha$ transcripts in gills subjected to hypoxia were observed (Figure 3B). This result resembles data obtained for gills by Mu et al. (2015) and Li et al. (2017) and from other tissues of fish species (Shen et al., 2010). However, Rissanen et al. (2006), combining hypoxia with exposure to different temperatures, observed an increase in hif- $1 \alpha$ transcripts in the gills of Carassius carassius. In our study, no changes in liver hif-1 $\alpha$ transcripts was observed (Figure 3A). Mu et al. (2015) and Li et al. (2017) also did not find differences in liver hif- $1 \alpha$ transcripts of other fish species exposed to hypoxia. Rissanen et al. (2006) also observed no differences in the levels of hif- $1 \alpha$ transcripts in the liver of Carassius carassius exposed to long periods of hypoxia at different temperatures $\left(18^{\circ} \mathrm{C}\right.$ and $\left.26^{\circ} \mathrm{C}\right)$. Although, Baptista et al. (2016) studying individuals of wild A. ocellatus with similar weight, noticed an increase in liver hif-l $\alpha$ transcripts after 3 hours of hypoxia exposure. Rytkonen et al. (2012) suggests that fish previously exposed to hypoxia amplify their transcriptional responses when compared to animals that experienced a single hypoxic stress. The hypoxia responses of hif- $1 \alpha$ transcripts in our study may not reflect its protein levels, as seen by Robertson et al. (2014), which observed an increase of HIF- $1 \alpha$ proteins even without a change in the amount of hif- $1 \alpha$ transcripts. For liver, we can hypothesize that a decrease in phd 2 transcripts levels, and the reduction of oxygen concentration, is enough to stabilize HIF-1 levels, since the degradation of HIF-1 $\alpha$ decreases, so the animal will no need to increase hif- $1 \alpha$ transcript levels.

In conclusion, hypoxia caused a decrease in liver glycogen, which was mobilized as plasma glucose to supply the switch to anaerobic metabolism, evidenced by the high levels of plasma lactate. Even though there is no change in hif- $1 \alpha$ transcripts levels, the different transcription patterns of phd 2 found in liver and gills indicate that these organs have different molecular strategies to cope with hypoxia. In our study, phd 2 response to hypoxia condition was observed at the first hour and the transcripts levels were constant during the 5 hours of hypoxia in both tissues. The decrease in liver phd 2 transcript levels, combined with the lactate increase, indicate a switch from aerobic to anaerobic metabolism, since the degradation of HIF-1 $\alpha$ should decrease. On the other hand, the increase in gills $p h d 2$ levels can indicate two responses: (1) a prioritization of aerobic metabolism for this tissue, or (2) a preparation for reoxygenation after hypoxia, since this tissue has direct contact to dissolved oxygen. Along with these results we can say that this high hypoxia tolerant fish, A. ocellatus, possess a rapid and well-established mechanism to deal with low levels of environmental oxygen.

\section{Acknowledgements}

This work was supported by the Brazilian National Research Council (CNPq) and Amazonas State Research Foundation (FAPEAM) through INCT-ADAPTA (\#465540/2014-7 and \#0621187/2017, respectively). The authors are grateful to Dr. Adalberto Luis Val, Dr. Derek Campos, MSc. Nazaré Paula-Silva and MSc. Luciana FéGonçalves for excellent contributions to this work. JLVL and VLOC were recipients of a MSc. fellowship from CNPq. WHC was a recipient of a $\mathrm{PhD}$ fellowship from $\mathrm{CNPq}$. VMFAV is a recipient of a research fellowship from $\mathrm{CNPq}$.

\section{Conflict of Interest}

The authors declare no competing or financial interests.

\section{Author Contributions}

VMFAV and JLVL conceived the study and planned the experimental design; JLVL, VLOC and WHC conducted the experiments; JLVL, VLOC and WHC analyzed the data; JLVL and WHC wrote the manuscript; VMFAV supervised all work stages and edited the manuscript. All authors read and approved the final version.

\section{References}

Almeida-Val VMF and Val AL (1993) Evolutionary trends of LDH isozymes in fishes. Comp Biochem Physiol Part B 105:21-28.

Almeida-Val VMF, Val AL and Walker I (1999) Long-and short-term adaptation of Amazon fishes to varying $\mathrm{O}_{2}$-levels: Intra-specific phenotypic plasticity and interspecific variation. In: Val AL and Almeida-Val VMF (eds). Biology of Tropical Fishes. INPA, Manaus, pp 185-206.

Appelhoff RJ, Tian Y-M, Raval RR, Turley H, Harris AL, Pugh CW, Ratcliffe PJ and Gleadle JM (2004) Differential function of the prolyl hydroxylases PHD1, PHD2, and PHD3 in the regulation of hypoxia-inducible factor. J Biol Chem 279:38458-38465.

Aprelikova O, Chandramouli GVR, Wood M, Vasselli JR, Riss J, Maranchie JK, Linehan WM and Barrett JC (2004) Regulation of HIF prolyl hydroxylases by hypoxia-inducible factors. J Cell Biochem 92:491-501.

Baptista RB, Souza-Castro N and Almeida-Val VMF (2016) Acute hypoxia up-regulates HIF-1 $\alpha$ and VEGF mRNA levels in Amazon hypoxia-tolerant Oscar (Astronotus ocellatus). Fish Physiol Biochem 42:1307-1318.

Berra E, Benizri E, Ginouvès A, Volmat V, Roux D and Pouysségur J (2003) HIF prolyl-hydroxylase 2 is the key oxygen sensor setting low steady-state levels of HIF- $1 \alpha$ in normoxia. EMBO J 22:4082-4090.

Bidinotto PM, Moraes G and Souza RHS (1997) Hepatic glycogen and glucose in eight tropical freshwater teleost fish: A procedure for field determinations of micro samples. Bol Tec CEPTA 10:53-60.

Cassidy AA, Driedzic WR, Campos D, Heinrichs-Caldas W, Almeida-Val VMF, Val AL and Lamarre SG (2018) Protein synthesis is lowered by 4EBP1 and eIF2- $\alpha$ signaling while protein degradation may be maintained in fasting, hypoxic Amazonian cichlids Astronotus ocellatus. J Exp Biol 221:jeb167601.

Chen N, Wu M, Tang GP, Wang HJ, Huang CX, Wu XJ, He Y, Zhang B, Huang CH, Liu H et al. (2017) Effects of acute hypoxia and reoxygenation on physiological and immune responses and redox balance of wuchang bream (Megalobrama amblycephala Yih, 1955). Front Physiol 8:375. 
Chen XQ, Dong J, Niu CY, Fan JM and Du JZ (2007) Effects of hypoxia on glucose, insulin, glucagon, and modulation by corticotropin-releasing factor receptor type 1 in the rat. Endocrinology 148:3271-3278.

Cheung CHY, Chiu JMY and Wu RSS (2014) Hypoxia turns genotypic female medaka fish into phenotypic males. Ecotoxicology 23:1260-1269.

Chippari-Gomes AR, Gomes LC, Lopes NP, Val AL and AlmeidaVal VMF (2005) Metabolic adjustments in two Amazonian cichlids exposed to hypoxia and anoxia. Comp Biochem Physiol Part B 141:347-355.

Cioffi CL, Liu XQ, Kosinski PA, Garay M and Bowen BR (2003) Differential regulation of HIF-1 $\alpha$ prolyl-4-hydroxylase genes by hypoxia in human cardiovascular cells. Biochem Biophys Res Commun 303:947-953.

Cui XG, Han ZT, He SH, Wu XD, Chen TR, Shao CH, Chen DL, Su $\mathrm{N}$, Chen YM, Wang T et al. (2017) HIF1/2 $\alpha$ mediates hypoxiainduced LDHA expression in human pancreatic cancer cells. Oncotarget 8:24840-24852.

D’Angelo G, Duplan E, Boyer N, Vigne P and Frelin C (2003) Hypoxia up-regulates prolyl hydroxylase activity. A feedback mechansim that limits HIF-1 responses during reoxygenation. J Biol Chem 278:38183-38187.

De Boeck G, Wood CM, Iftikar FI, Matey V, Scott GR, Sloman KA, Silva MNP, Almeida-Val VMF and Val AL (2013) Interactions between hypoxia tolerance and food deprivation in Amazonian oscars, Astronotus ocellatus. J Exp Biol 216:4590-4600.

Dubois M, Gilles KA, Hamilton JK, Rebers PA and Smith F (1956) Colorimetric method for determination of sugars and related substances. Anal Chem 28:350-356.

Epstein ACR, Gleadle JM, McNeill LA, Hewitson KS, O'Rourke J, Mole DR, Mukherji M, Metzen E, Wilson MI and Dhanda A (2001) C. elegans EGL-9 and mammalian homologs define a family of dioxygenases that regulate HIF by prolyl hydroxylation. Cell 107:43-54.

Heath AG and Pritchard AW (1962) Changes in the metabolic rate and blood lactic acid of bluegill sunfish, Lepomis macrochirus, Raf. following severe muscular activity. Physiol Zool 35:323-329.

Heinrichs-Caldas W, Campos DF, Paula-Silva MN and AlmeidaVal VMF (2019) Oxygen-dependent distinct expression of hif- $1 \alpha$ gene in aerobic and anaerobic tissues of the Amazon Oscar, Astronotus crassipinnis. Comp Biochem Physiol Part B 227:31-38.

Hochachka PW and Somero G (1984) Biochemical Adaptation. Princeton University Press, New Jersey, $560 \mathrm{p}$.

Junk WJ, Bayley PB and Sparks RE (1989) The flood-pulse concept in river-floodplain systems. Can Spec Publ Fish Aquat Sci 106:110-127.

Kaelin WG (2005) Proline hydroxylation and gene expression. Annu Rev Biochem 74:115-128.

Kaelin Jr WG and Ratcliffe PJ (2008) Oxygen sensing by metazoans: The central role of the HIF hydroxylase pathway. Mol Cell 30:393-402.

Kewley RJ, Whitelaw ML and Chapman-Smith A (2004) The mammalian basic helix-loop-helix/PAS family of transcriptional regulators. Int J Biochem Cell Biol 36:189-204.

Kodama K, Rahman MS, Horiguchi T and Thomas P (2012) Upregulation of hypoxia-inducible factor (HIF)- $1 \alpha$ and HIF- $2 \alpha$ mRNA levels in dragonet Callionymus valenciennei exposed to environmental hypoxia in Tokyo Bay. Mar Pollut Bul 64:1339-1347.

Lewis JM, Costa I, Val AL, Almeida-Val VMF, Gamperl AK and Driedzic WR (2007) Responses to hypoxia and recovery: repayment of oxygen debt is not associated with compensatory protein synthesis in the Amazonian cichlid, Astronotus ocellatus. J Exp Biol 210:1935-1943.
Li HL, Gu XH, Li BJ, Chen X, Lin HR and Xia JH (2017) Characterization and functional analysis of hypoxia-inducible factor HIF1a and its inhibitor HIF 1an in tilapia. PLoS One 12:e0173478.

Marxsen JH, Stengel P, Doege K, Heikkinen P, Jokilehto T, Wagner T, Jelkmann W, Jaakkola P and Metzen E (2004) Hypoxiainducible factor-1 (HIF-1) promotes its degradation by induction of HIF- $\alpha$-prolyl-4-hydroxylases. Biochem J 381:761-767.

Maxwell PH, Wiesener MS, Chang GW, Clifford SC, Vaux EC, Cockman ME, Wykoff CC, Pugh CW, Maher ER and Ratcliffe PJ (1999) The tumour suppressor protein VHL targets hypoxiainducible factors for oxygen-dependent proteolysis. Nature 399:271-275.

Metzen E, Stiehl DP, Doege K, Marxsen JH, Hellwig-Bürgel T and Jelkmann W (2005) Regulation of the prolyl hydroxylase domain protein 2 (phd2/egln-1) gene: Identification of a functional hypoxia-responsive element. Biochem J 387:711717.

Moore CEJ, Mikolajek H, Regufe da Mota S, Wang X, Kenney JW, Werner JM and Proud CG (2015) Elongation factor 2 kinase is regulated by proline hydroxylation and protects cells during hypoxia. Mol Cell Biol 35:1788-1804.

Mu W, Wen H, Li J and He F (2015) HIFs genes expression and hematology indices responses to different oxygen treatments in an ovoviviparous teleost species Sebastes schlegelii. Mar Environ Res 110:142-151.

Muusze B, Marcon J and Almeida-Val VMF (1998) Hypoxia tolerance of Amazon fish: Respirometry and energy metabolism of the cichlid Astronotus ocellatus. Comp Biochem Physiol Part A 120:151-156.

Nikinmaa M and Rees BB (2005) Oxygen-dependent gene expression in fishes. Am J Physiol Integr Comp Physiol 288:R1079R1090.

Padmavathy P and Ramanathan N (2010) Quantitative changes of glycogen and lactate in muscle, blood and liver tissues of Oreochromis mossambicus under hypoxia and recovery. Tamilnadu J Vet Anim Sci 6:54-59.

Pescador N, Cuevas Y, Naranjo S, Alcaide M, Villar D, Landázuri MO and Del Peso L (2005) Identification of a functional hypoxiaresponsive element that regulates the expression of the egl nine homologue 3 (egln3/phd3) gene. Biochem J 390:189-197.

Pfaffl M (2004) Quantification strategies in real-time PCR. In: Bustin SA (ed). A-Z quantitative PCR. International University Line, La Jolla, pp. 87-120.

Rashid I, Nagpure NS, Srivastava P, Kumar R, Pathak AK, Singh M and Kushwaha B (2017) HRGFish: A database of hypoxia responsive genes in fishes. Sci Rep 7:42346.

Richards JG, Wang YS, Braune CJ, Gonzalez RJ, Patrick ML, Schulte PM, Chippari-Gomes AR, Almeida-Val VMF and Val AL (2007) Metabolic and ionoregulatory responses of the Amazonian cichlid, Astronotus ocellatus, to severe hypoxia. J Comp Physiol B Biochem Syst Environ Physiol 177:361-374.

Rissanen E, Tranberg HK, Sollid J, Nilsson GE and Nikinmaa M (2006) Temperature regulates hypoxia-inducible factor-1 (HIF-1) in a poikilothermic vertebrate, crucian carp (Carassius carassius). J Exp Biol 209:994-1003.

Robertson CE, Wright PA, Köblitz L and Bernier NJ (2014) Hypoxiainducible factor-1 mediates adaptive developmental plasticity of hypoxia tolerance in zebrafish, Danio rerio. Proc Biol Sci 281:20140637.

Romero-Ruiz A, Bautista L, Navarro V, Heras-Garvín A, MarchDíaz R, Castellano A, Gómez-Díaz R, Castro MJ, Berra E, López-Barneo J and Pascual A (2012) Prolyl hydroxylasedependent modulation of eukaryotic elongation factor 2 activity and protein translation under acute hypoxia. J Biol Chem 287:9651-9658. 
Rytkonen KT, Renshaw GMC, Vainio PP, Ashton KJ, WilliamsPritchard G, Leder EH and Nikinmaa M (2012) Transcriptional responses to hypoxia are enhanced by recurrent hypoxia (hypoxic preconditioning) in the epaulette shark. Physiol Genomics 44:1090-1097.

Rytkönen KT, Williams TA, Renshaw GM, Primmer CR and Nikinmaa M (2011) Molecular evolution of the metazoan PHD-HIF oxygen-sensing system. Mol Biol Evol 28:1913-1926.

Scarabello M, Heigenhauser GJ and Wood CM (1992) Gas exchange, metabolite status and excess post-exercise oxygen consumption after repetitive bouts of exhaustive exercise in juvenile rainbow trout. J Exp Biol 167:155-169.

Schulte PM, Moyes CD and Hochachka PW (1992) Integrating metabolic pathways in post-exercise recovery of white muscle. J Exp Biol 166:181-195.

Scott GR, Wood CM, Sloman KA, Iftikar FI, De Boeck G, Almeida-Val VMF and Val AL (2008) Respiratory responses to progressive hypoxia in the Amazonian oscar, Astronotus ocellatus. Respir Physiol Neurobiol 162:109-116.

Semenza GL (2004) Hydroxylation of HIF-1: Oxygen sensing control of oxygen-regulated gene. Physiol 19:176-182.

Semenza GL (2002) Signal transduction to hypoxia-inducible factor 1. Biochem Pharmacol 64:993-998.

Semenza GL (1998) Hypoxia-inducible factor 1: Master regulator of $\mathrm{O}_{2}$ homeostasis. Curr Opin Genet Dev 8:588-594.

Shen RJ, Jiang XY, Pu JW, Zou SM (2010) HIF- $1 \alpha$ and $-2 \alpha$ genes in a hypoxia sensitive teleost species Megalobrama amblycephala: cDNA cloning, expression and different responses to hypoxia. J Comp Biochem Physiol B 157:273-280.

Sloman KA, Wood CM, Scott GR, Wood S, Kajimura M, Johannsson OE, Almeida-Val VMF and Val AL (2006) Tribute to R.G. Boutilier: The effect of size on the physiological and behavioural responses of oscar, Astronotus ocellatus, to hypoxia. J Exp Biol 209:1197-1205.

Stiehl DP, Wirthner R, Köditz J, Spielmann P, Camenisch G and Wenger RH (2006) Increased prolyl 4-hydroxylase domain proteins compensate for decreased oxygen levels: Evidence for an autoregulatory oxygen-sensing system. J Biol Chem 281:23482-23491.
Suhara T, Hishiki T, Kasahara M, Hayakawa N, Oyaizu T, Nakanishi T, Kubo A, Morisaki H, Kaelin WG, Suematsu M and Minamishima YA (2015) Inhibition of the oxygen sensor PHD2 in the liver improves survival in lactic acidosis by activating the Cori cycle. Proc Natl Acad Sci U S A 112:11642-11647.

Val AL (1995) Oxygen transfer in fishes: Morphological and molecular adjustments. Brazilian J Med Biol Res 28:1119-1127.

Val AL, Silva MNP and Almeida-Val VMF (1998) Hypoxia adaptation in fish of the Amazon: A never-ending task. South African J Zool 33:107-114.

Wang H, Huang C, Chen N, Zhu K, Chen B, Wang W and Wang H (2015) Molecular characterization and mRNA expression of HIF-prolyl hydroxylase-2 (phd2) in hypoxia-sensing pathways from Megalobrama amblycephala. Comp Biochem Physiol Part B 186:28-35.

Wenger RH, Stiehl DP and Camenisch G (2005) Integration of oxygen signaling at the consensus HRE. Sci STKE 2005:re12.

Wood CM, Kajimura M, Sloman KA, Scott GR, Walsh PJ, AlmeidaVal VMF and Val AL (2007) Rapid regulation of $\mathrm{Na}^{+}$fluxes and ammonia excretion in response to acute environmental hypoxia in the Amazonian oscar, Astronotus ocellatus. AJP Regul Integr Comp Physiol 292:R2048-R2058.

Zhang G, Zhao C, Wang Q, Gu Y, Li Z, Tao P, Chen J and Yin S (2017) Identification of HIF-1 signaling pathway in Pelteobagrus vachelli using RNA-Seq: Effects of acute hypoxia and reoxygenation on oxygen sensors, respiratory metabolism, and hematology indices. J Comp Physiol B Biochem Syst Environ Physiol 187:931-943.

Associate Editor: Catarina Satie Takahashi

License information: This is an open-access article distributed under the terms of the Creative Commons Attribution License (type CC-BY), which permits unrestricted use, distribution and reproduction in any medium, provided the original article is properly cited. 